\title{
KRAS Exon 4 Mutation
}

National Cancer Institute

\section{Source}

National Cancer Institute. KRAS Exon 4 Mutation. NCI Thesaurus. Code C135717.

A molecular genetic abnormality indicating the presence of a mutation in exon 4 of the KRAS gene. 